\title{
月経周期に伴った声帯出血の一例
}

\author{
大津 信也・武市佳代子 \\ 幸田＼cjkstart純治・宇高 二良
}

\section{A Case of Hemorrhage of the Vocal Cords}

\author{
Shinya Ohtsu, Kayoko Takeichi, \\ Jnnji Kohda and Jiro Udaka
}

(The University of Tokushima School of Medicine)

A case of vocal cord hemorrhage is reported. The patient was a 50-year-old woman, in whom hoarseness is associated with her menstrual cycle. On laryngoscopic examination, the vocal cords were edematous and submucosally hemorrhaged during menstruation, but almost normal during nonmenstruation. Hormonal checkup revealed an abnormally high level of estradiol at the early period of menstruation. After menopause, these findings and symptoms disappeared.

Key words: vocal cord hemorrhage, menstrual cycle, hoarseness

\section{緒 言}

声帶の出血病変の原因としては, 物理的科学 的刺激によるもの，著名な炎症によるあのなど が主に考えられているが，内因的な原因によっ ても抗てりうると報告されている122.

内因性の声滞の出血性病変は女性に多く, 特 に更年期及び閉経後に多く認められるといわれ ている．また月経周期に関連しているあのあみ られる.しかし, 現在までにホルモン学的に詳 細な検討がなされた例はない．

今回，我々は更年期に入ったと思わ饥る女性 で，月経前期より月経期にかけてのみ嗄声を訴 え，その時期のみに声带に出血を認めた症例を 経験し，一月経周期にわたりホルモン测定を行 ない得たので, 若干の考察を加えて報告する.

\section{症例}

患者: , 女性, 50才, 看護婦。
初診：昭和62年 1 月 27 日

主訴 : 嗄声, のどのつまる感じ.

家族歷：特記すべきことなし。

既往歴: $30 才$, 右卵宩摘出術 (卵宩囊腫)

現病歷：40才頃より嗄声出現し，42才時に声 带ポリープを指摘され, 某医にて喉頭微細手術 を施行された。 以後症状は改善していた。

昭和59年頃より，カラオケを始めたが, 同じ 頃より時々嗄声，のどのつまる感じが出現する ようになった。

炤和 61 年 3 月頃よりは，特に月経期に症状が 憎悪し，月経終了とともに筧解するようになっ たため，7月某耳鼻咽喉科を受診した。 月経期 に一致した声带の出血を指摘され，精查日的に て当科を紹介された.

なお，声帶出血の他に歯肉出血屯認めること が時々あった。 
・初診洔所見

全身所見：特記すべきことなし，

耳鼻咽喉科的所見:耳, 鼻, 咽頭に著変な

し. 喉頭では右声带に出血斑が認められた。

- 初診時検査成績

尿検査：潜血 $(+)$

末梢血液検查：藷変なし

血液生化学検查：著変なし

血清ホルモン検查：（）内は正常範盲

$\begin{array}{lrl}\mathrm{ACTH} & 13.7 \mathrm{pg} / \mathrm{ml}(<100) \\ \mathrm{GH} & 2.0 \mathrm{ng} / \mathrm{ml}(<5) \\ \mathrm{TSH} & 1.9 \mu \mathrm{U} / \mathrm{ml}(<10)\end{array}$

T 3

$1.11 \mathrm{ng} / \mathrm{ml}(0.86 \sim 2.30)$

$\mathrm{T} 4$

$7.9 \mu \mathrm{g} / \mathrm{ml}(4.5 \sim 11.8)$

PRL

$6.8 \mathrm{ng} / \mathrm{ml}(2.7 \sim 20.3)$

FSH

13. $1 \mathrm{mIU} / \mathrm{ml}$

$\mathrm{LH}$

$6.9 \mathrm{mIU} / \mathrm{ml}$

Progesterone $23 \mathrm{ng} / \mathrm{ml}$

Estradiol $18 \mathrm{pg} / \mathrm{ml}$

出血時間

2 分 30 秒

全血漿凝固時間 8 分

PT 13秒

APTT 42秒

Rumpel-Leede (-)

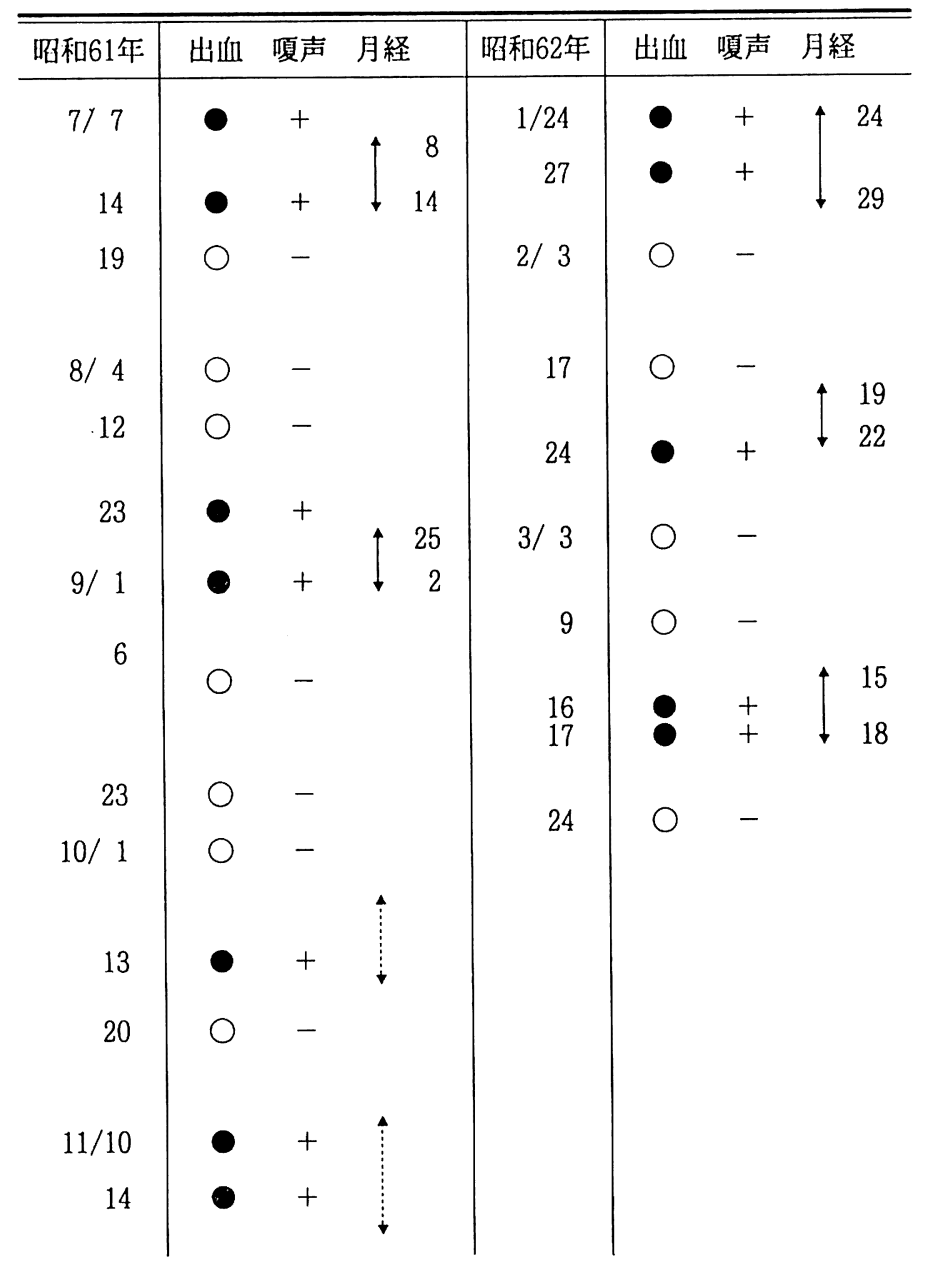

図 I 経過図

- : 声帯出血 $(+), 0$ : 声带出血 $(-)$

：確定しえた月経の期間，………推定した月経の期間 
前医及び当科での症状, 視䯧所見, 月経との 関係を図 1 亿示す.

・喉頭所見の推移

昭和 62 年 1 月 27 日（月経周期 4 日目）（図

2)

雨側声带発赤 $(+)$

右側声帯出血斑 $(+)$

昭和 62 年 2 月 3 日（月経周期11日目）（図 3)

雨側声帯に発赤, 出血斑 (一)

昭和 62 年 3 月 16 日（月経周期 2 日目）

4)

両側声带 浮腫状

左側声带 出血归: (+) 発赤 $(+)$

・音声分析

月経周期15日目の音声（母音/ e / ) 及び月経 周期 2 日目の音声（母:音/ e / ) のスペクトル分 析結果在 5 に示す。音響学的に, 月経期で は, 非月経期に比し $3000 \sim 4500 \mathrm{~Hz}$ 付近の高

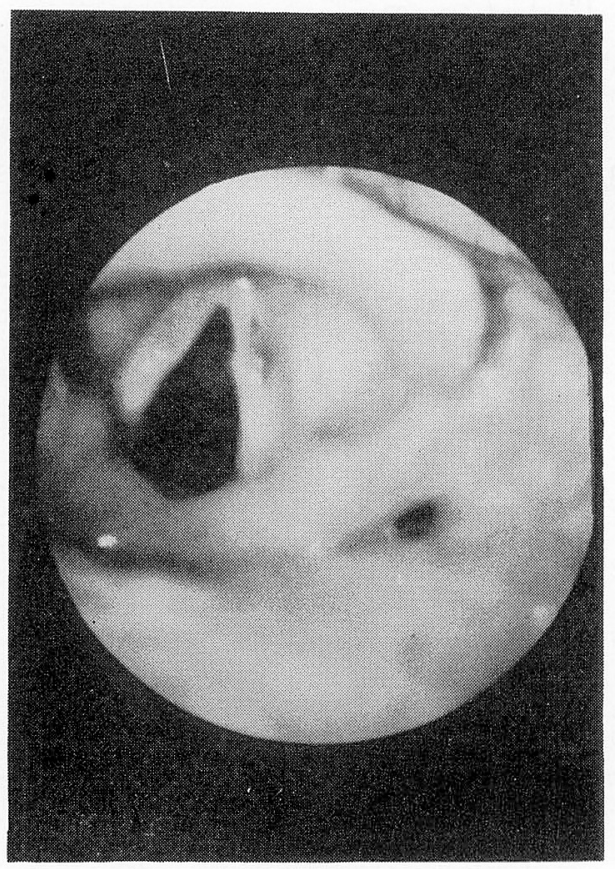

図 2 月経周期 4 日目の声帯

両側の声帯の発赤と右側の声帯に出血斑が認めら れる.

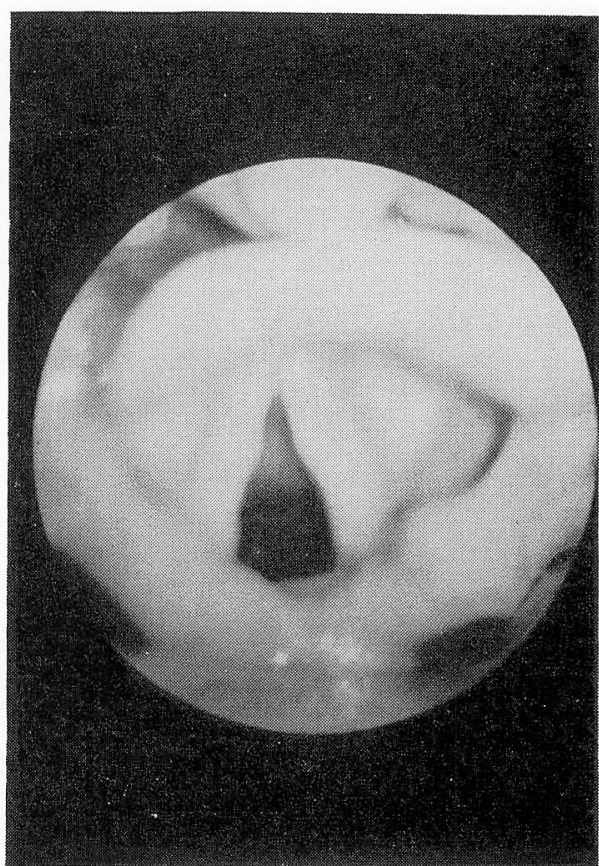

図 3 月経周期11日目の声帯 異常は認められない。

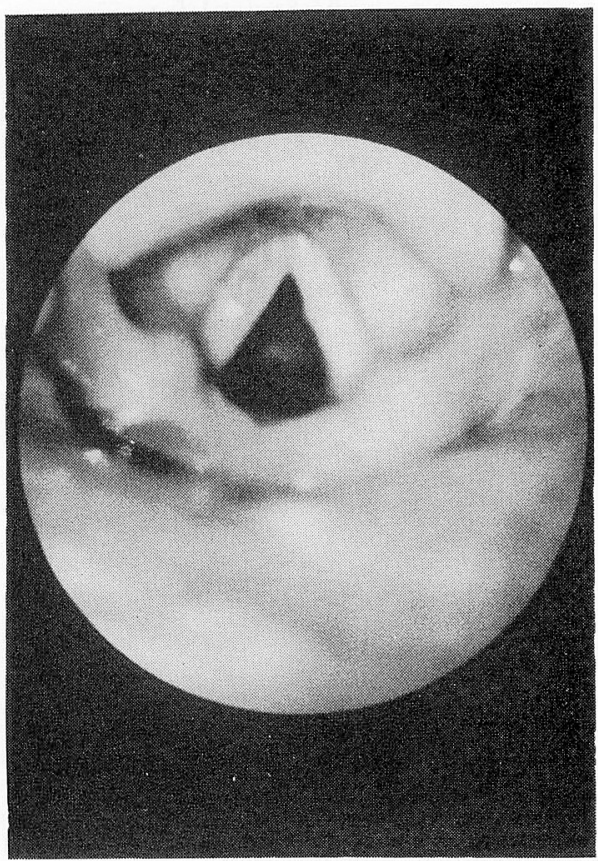

図 4 月経周期 2 日目の声带 両側の声带の浮腫状変化と左側の声帯の発赤と出 血斑が認められる。 
調波成分の増加が認められた

・血中ホルモン值の推移

4 月 1 日より 5 月 2 日までの血中の $\mathrm{FSH}$,

LH, Progesterone, Estradiol の测定值を図 6 亿示す.
LH は月経前期に正常より低值を示した。 FSH は正常パターンとは著明な差異を慜めた。 Progesterone は正常婦人とほぼ同じパターン を示した。Estradiol は月経前期に高值加ら の急激な低下を恐めた。

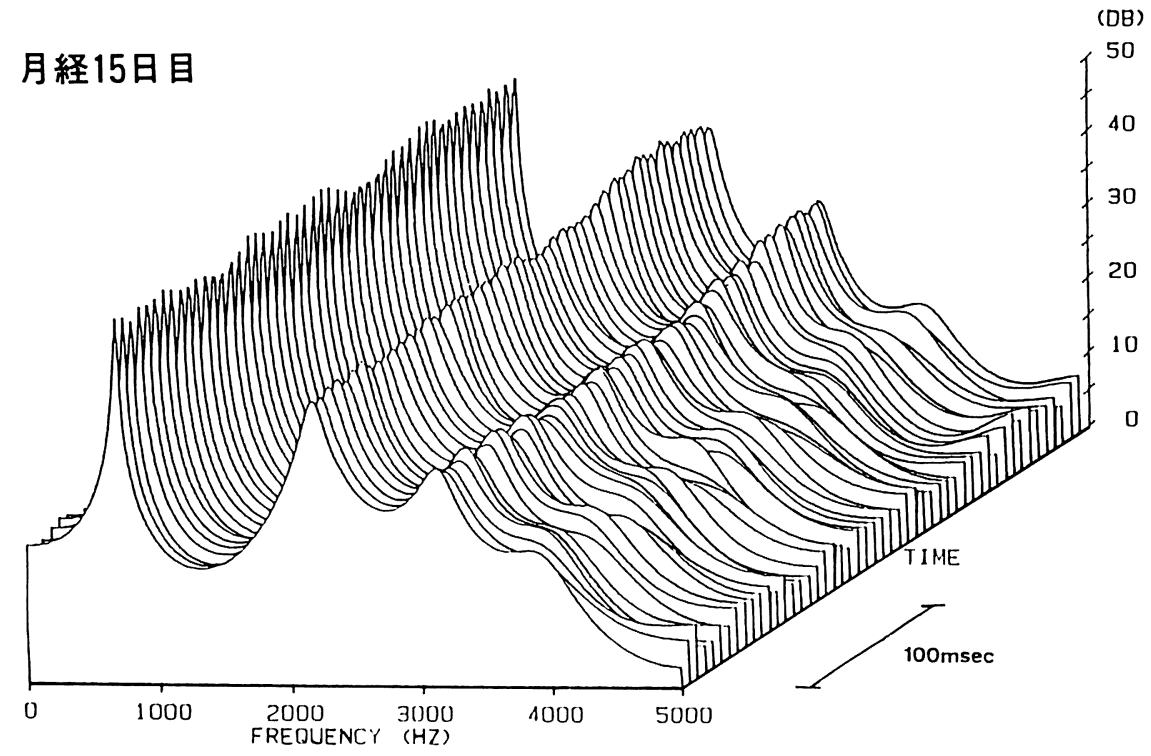

月経 2 日目

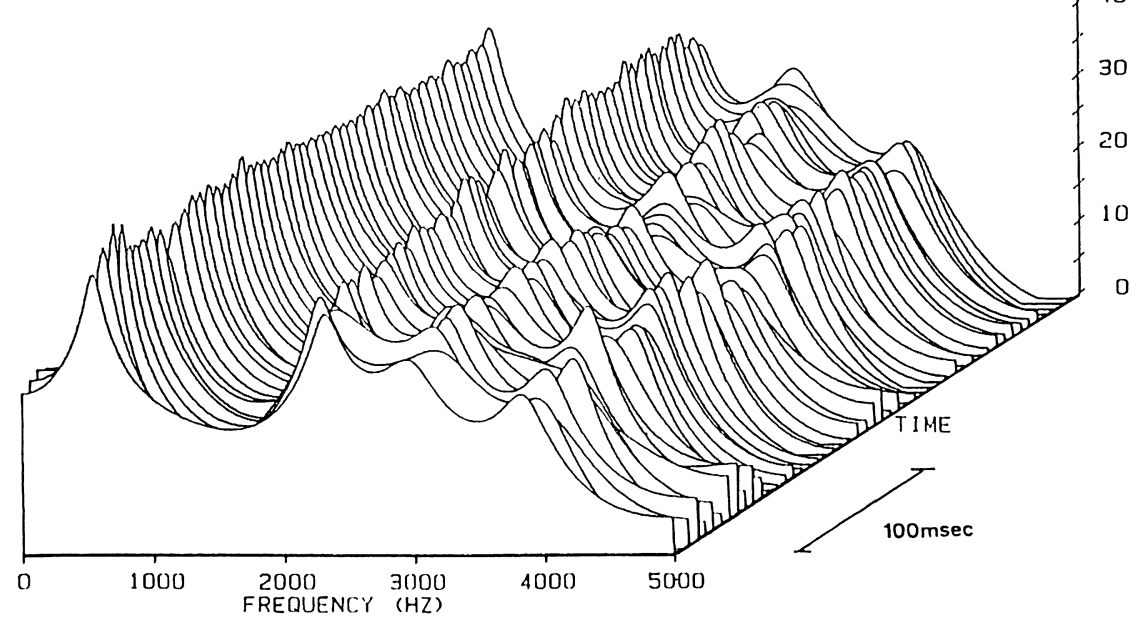

図 5 母音/e/のスペクトル分析図

上段：月経周期 15 日目，下段：月経周期 1 日目

上段に比し下段では $3 \mathrm{kHz}$ 以上の高調波成分の増強が浔められる。 
・経過

月経周期に伴ない症状を反復したが，ホルモ ン值测定以後は，極めて月経不順となり，更に 閉経となって，現在月経を認めない，閉経以後

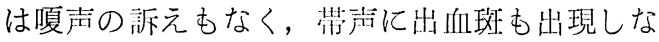
い.

\section{考案}

内因性の声带出血を取り上げた報告は少な く，本邦では，石井らにより18例が報告されて いるのが目立つ程度である．石井の症例のうち 月経周期に一致して症状の変化のあるあのは 1 例のみであり，その症例においてはホルモン学 的検討は十分に行なわれていない.

Brodnitz ${ }^{4)}$ は月経前期に反復して，声带に 出血を認めたオペラ歌手の 1 例を経験し，ホル モン学的検索により, LH の低下を認め, ホル モン投与により治療しえたと報告している.
本症例において屯月経前期に LH の低值を認 め, 声带出血と LH との関連が示唆される (図6).

Frable $^{5)}$ は，月経前期の嗄声の発現機序と して，エストロゲンの増加に伴って組織中の基 本物質である高分子多糖体が増量しているとて ろに，月経前期のエストロゲンの急激な低下に より，組織中のこれら多糖体の破壊がひきおこ され，同時に血管透過性の充進肪抢こり，その 結果声带の容量が増加し, 嗄声が出現する, と 述べている，本症例の測定絬果にても，正常よ り高值であった Estradiol の值が月経前期に は急激に低下している（図6）。このこよよ り，嗄声出現の機序としての Frable の説は 支持しうるあのであろうと考える.

また，石井ら ${ }^{2)}$ は声带出血の成因として，工 ストロゲンの止血作用をあげ，エストロゲンの
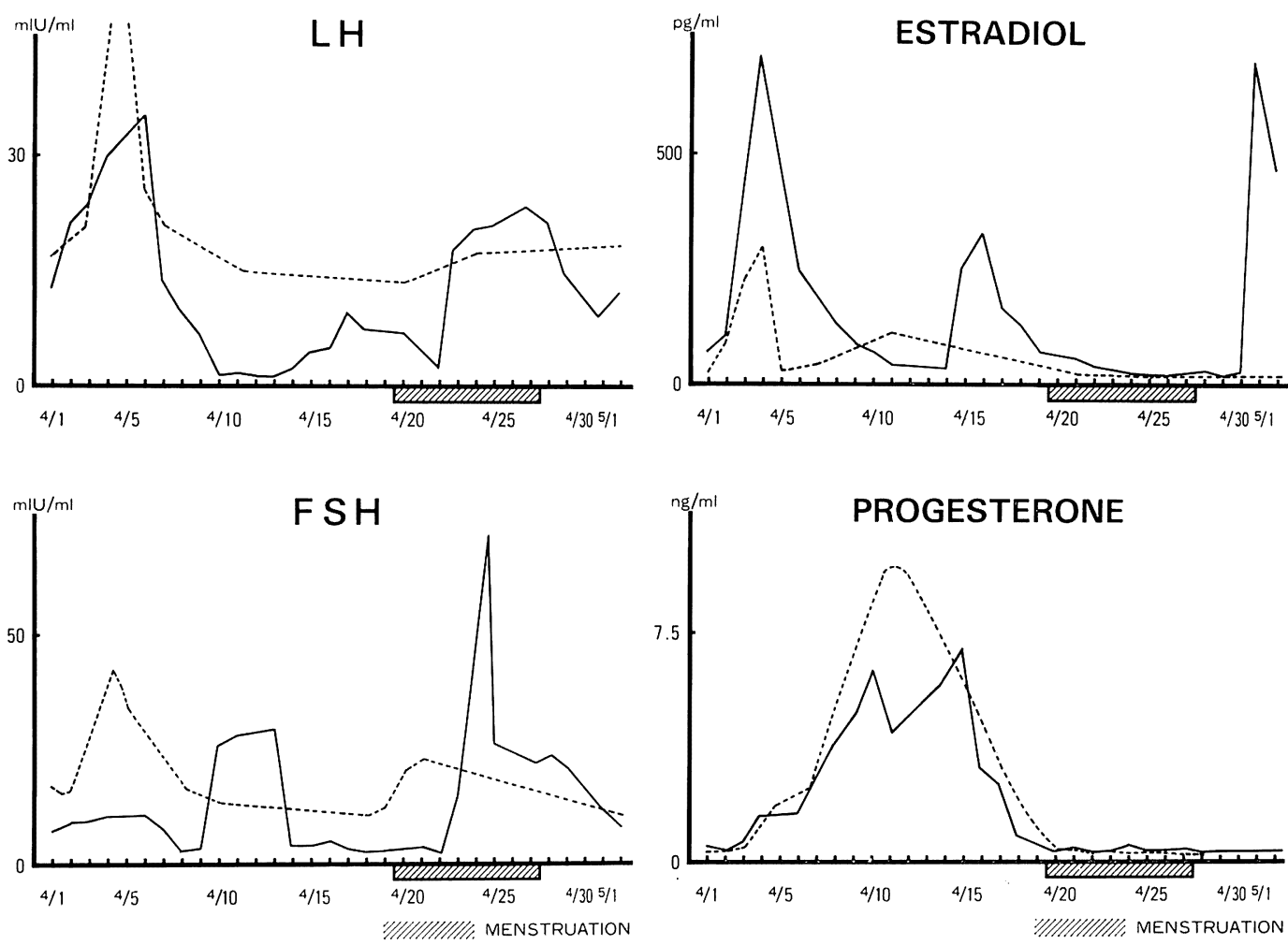

図 6 血中ホルモン值の推移

垁線：本症例，破線：正常婦人のパターン，横軸上の斜経は月経期間を示す。 
低值が出血傾向を増大させるために, 声带出血 がひきおこされる可能性がある，と述べてい る. 本症例の場合, 検査值の上からは出血傾向 の增大は認められないが，月経期に䀞肉出血が 出現していることより, 易出血性の状態にあっ たことは確かなようである.

さらに, Frable, Brodnitz の報告によれば, 内因性の声帯出血の誘因として, 声の酷使が考 えられる. 本症例に抢いてもカラオケを趣味と していた。 即ち, ホルモンの不均衡により声带 に何らかの変化が生じ，それに声の酷使という 誘因が加わったために，声带の出血がひきおて された，ということが考えられる.

日常䛦療においては，局所所見を重視するあ まり，全身的な関与については等閉視する傾向 にあり，本報告のような症例は比較的見逃され がちであると考えられる，今後，診察にあたっ ては注意すべき疾患であろう。

\section{結 語}

月経期に反復して嗄声を訴え, 声带に出血を 認めた症例を経験し，1月経周期間にわたって ホルモン測定を行ない, 月経前期から月経期に
かけての LH の低下と Estradiol の高值から の急激な低下を確認した。 また音声分析も行な い, 若干の文献的考察を加えて報告した。

稿を終えるにあたり，御校閲をいただいた小池靖夫 教授に深謝致します.

\section{参考文献}

1) Otto HM : On laryngeal bleeding. Acta Otolaryngol $38: 27 \sim 30,1950$.

2 ) 石井英男, 豊田 修: 出血性声帯炎の臨床. 気食 $20: 43 \sim 50,1970$.

3) Silverman EM and Zimmer $\mathrm{CH}$ : Effect of the menstrual cycle on voice quality. Arch Otolaryngol 104: 7 10, 1978.

4) Brodnitz S: Hormone and the human voice. Bull NY Acad Med 47:183 191, 1971.

5) Frable MAS : Hoarseness; A symptom of premenstrual tension. Arch Otolaryngol 75 : 66 68, 1962 .

別刷請求先 : 大津信也 干770 德島市藏本町 1 丁目 徳島県立中央病院耳鼻咽喉科 